TRAVEL BEHAVIOUR OF ASIAN \& EUROPEAN IMMIGRANTS IN THE GREATER TORONTO AND HAMILTON AREA

by

\author{
Niranjan Rajevan \\ BES, University of Waterloo, 2018 \\ A Major Research Paper \\ Presented to Ryerson University \\ In partial fulfillment of the requirements for the degree of \\ Master of Planning \\ in \\ Urban Development
}

Toronto, Ontario, Canada, 2020

(C) Niranjan Rajevan 2020 


\section{AUTHOR'S DECLARATION}

I hereby declare that I am the sole author of this MRP. This is a true copy of the MRP, including any required final revisions.

I authorize Ryerson University to lend this paper to other institutions or individuals for the purpose of scholarly research.

I further authorize Ryerson University to reproduce this MRP by photocopying or by other means, in total or in part, at the request of other institutions or individuals for the purpose of scholarly research.

I understand that my MRP may be made electronically available to the public. 


\title{
TRAVEL BEHAVIOUR OF ASIAN \& EUROPEAN IMMIGRANTS IN THE GREATER TORONTO AND HAMILTON AREA
}

(C) Niranjan Rajevan 2020

\author{
Master of Planning \\ in \\ Urban Development \\ Ryerson University
}

\begin{abstract}
Without a better understanding of travel behaviour by diverse immigrant groups, the nuances of immigrant mobility needs may go unmet. Statutory transportation planning requirements focus on mobility "needs". But social understandings of what travel is "needed" for daily life changes over time varies between different population groups. In many major immigrant settlement areas, immigration has become the primary, if not sole, reason for population growth (Thomas, 2013). Evidence continues to emerge indicating that immigrants use non-auto modes significantly more than non-immigrants but slowly assimilate in becoming more auto-oriented (Chatman, 2013). Likewise, mobility differences between ethnic groups persist (Hu et al., 2020). In the absence of an understanding of the travel behaviour of specific immigrant groups and changes over time, there is a distinct possibility for a significant disconnect between understandings of what transportation services are provided and what services are needed (Blumenberg, 2009; Chatman \& Klein, 2009). Towards bridging this gap, this study explores auto ownership and daily vehicle travel among self-identified immigrants and non-immigrants of either self-identified Asian or European descent in the Greater Toronto and Hamilton area.
\end{abstract}


Using data from a 2018 travel survey of residents of the Greater Toronto and Hamilton Area, this study explores travel behaviour in relation to immigrant status and the length of residence in Canada and several mobility measures, including vehicle travel and auto ownership. This study begins by using the survey data to present descriptive statistics related to differences between immigrant groups, based on length of residence in Canada and based on auto ownership and vehicle-kilometers traveled (VKT). Next, inferential models were estimated to formally test the links between travel behaviour outcomes and immigrant status. Logistic regression models of household vehicle ownership were estimated before Tobit regression models of daily VKT were estimated.

Descriptive study findings support the expectation of significant differences between immigrant status (based on length of stay) and self-identified ethnicity (Asian or European) and both vehicle ownership and VKT. However, inferential models show a more complex story. Models of household vehicle ownership (yes/no) indicate that being a recent immigrant to Canada is associated with lower vehicle ownership rates, but that effects attenuate rapidly implying rapid assimilation. Tobit models from this study of daily VKT suggest that these lower rates of auto ownership translate weakly into VKT reductions. Evidence is suggestive of a VKT rebound among Asian populations - wherein some immigrants exceed VKT expectations of nonimmigrant groups. These findings beg to question why Asian immigrants use their vehicles so intensely and how mobility gaps are overcome so quickly.

\section{Key Words}

Asian immigrants, European immigrants, travel behaviour, assimilation, Toronto, Hamilton 


\section{ACKNOWLEDGEMENTS}

I would like to acknowledge and thank Professor Matthias Sweet for being my supervisor and guiding me through the MRP process and data collection through RA (Research Assistant) work for the past 16 months. I thoroughly enjoyed working with Professor Sweet and 1 learned a vast amount of knowledge from him regarding transportation planning and using R-Studio coding software. At the start of my RA position, I had no knowledge or experience in using R. However, Professor Sweet was very patient in teaching me from the basics to creating complicated regression models. He was always available to answer any questions or to help me solve any issues I faced during the process. He also suggested this topic for my MRP which I found very interesting and something I can connect to as my parents are immigrants. I am very grateful to have an enthusiastic transportation policy expert as my supervisor and am excited to continue to work with him on making this MRP into a scholarly paper for the ACSP (Association of Collegiate Schools of Planning) Conference in November 2020. I would also like to thank Professor Zhixi Zhuang for being the second reader for my MRP and for agreeing to co-author the paper for the ACSP conference. Her expertise and interests in multicultural planning and placemaking will assist in creating this paper of Immigrant Travel Behaviour in the GTHA into a strong and influential manuscript.

I would also like to thank Neerja Rajevan and Amanda Morris for editing my MRP and assisting in strengthening the tone and language used throughout the paper. Neerja Rajevan is my sister and assisted me in the first round of edits. Amanda Morris is a graduate support consultant for Ryerson's Student Learning Support and spent five 1-hour sessions with me to go through the full draft of my MRP and suggest any changes or edits that assisted in making this into a strong paper. I am grateful to both Neerja and Amanda for taking the time in assisting me to edit my MRP thoroughly. 


\section{TABLE OF CONTENTS}

$\begin{array}{ll}\text { AUTHOR'S DECLARATION } & 2\end{array}$

$\begin{array}{ll}\text { ABSTRACT } & 3\end{array}$

$\begin{array}{ll}\text { Key Words } & 4\end{array}$

ACKNOWLEDGEMENTS $\quad 5$

$\begin{array}{ll}\text { TABLE OF CONTENTS } & 6\end{array}$

$\begin{array}{ll}\text { LIST OF FIGURES } & 7\end{array}$

$\begin{array}{ll}\text { LIST OF TABLES } & 8\end{array}$

$\begin{array}{lr}\text { BACKGROUND } & 9\end{array}$

LITERATURE REVIEW

Social \& Income Factors $\quad 12$

$\begin{array}{ll}\text { Travel Commute Mode } & 14\end{array}$

$\begin{array}{ll}\text { Immigrants and Opportunity } & 19\end{array}$

$\begin{array}{ll}\text { Takeaways } & 21\end{array}$

$\begin{array}{ll}\text { RESEARCH DESIGN } & 22\end{array}$

Study Area \& Canadian Studies $\quad 23$

$\begin{array}{ll}\text { Method } & 25\end{array}$

$\begin{array}{ll}\text { RESULTS } & 27\end{array}$

$\begin{array}{ll}\text { Descriptive Findings } & 27\end{array}$

$\begin{array}{ll}\text { Model results using RStudio } & 29\end{array}$

$\begin{array}{ll}\text { CONCLUSION } & 34\end{array}$

$\begin{array}{ll}\text { APPENDIX } & 37\end{array}$

$\begin{array}{lc}\text { REFERENCES } & 38\end{array}$ 


\section{LIST OF FIGURES}

Figure 1: Socially Disadvantaged Neighbourhoods in Montreal

Figure 2: Mean Commute Distance in kilometres

Figure 3: Comparing the relationship between Years of Immigration \& Travel Trip Distance

Figure 4: Comparing the relationship between Years of Immigration \& Vehicle Ownership 


\section{LIST OF TABLES}

Table 1: Comparing public transit commuters

Table 2: Difference of Means Two Sample T-test

Table 3: Logit Model - Whether Respondent's Household Owns >= 1 Vehicle

Table 4: Tobit Model - Vehicle Kilometers Travelled Yesterday

Table 5: Final Tobit \& Logit Model Summary Results 


\section{BACKGROUND}

Transportation planning is conventionally based on empirical estimates of typical travel behaviour among residents in a region. Traditional models estimate the outlook to reduce travel burdens based on the amount of travel individuals engage in and based on economic valuations of travel cost reductions, such as time savings. However, research in other contexts suggests that new immigrants travel less than longer-residing immigrants or than locally-born populations (Blumenberg 2008 \& 2011; Giuliano, 2004). In fact, most growth in Canada and the United States, including in the Greater Toronto and Hamilton Area of Southern Ontario, comprises of new immigrants, rather than residents born in Canada. As such, while immigrants represent a significant new population and travel market, their different travel needs (notably lower rates of mobility) lead current transportation planning and travel demand forecasting practices to be less aligned towards immigrants, instead prioritizing highly mobile sectors of society. By developing a better understanding of immigrant travel behaviour in the GTHA, specifically immigrants from Asian origins, this study proposes to bridge the imperative to plan for immigrants and the deficiency in data and information on immigrant travel used in current transportation planning practice.

This study aims to explore the differences in Asian immigrant and non-immigrant travel behaviour across different years of immigrations in the GTHA. With the rapidly increasing number of immigrants in Canada, it is key to understand these relationships and how Canadian immigrants \& ethnic populations travel. Immigrants represent the rapidly growing population of many Canadian cities with $48 \%$ of the population in Toronto's CMA being immigrants making the highest foreign-born metropolitan population in the world (Thomas, 2013a). Therefore, it is crucial to understand immigrants' choices and preferences as this will influence regional and municipal growth management. However, immigration has replaced natural population growth 
within Canada as the birth rate has declined, the percentage of single-parent and single-person households has increased, and household sizes has decreased (Hulchanski, 2007; Thomas, 2013a). Results created using the 2016 Canadian Census indicate that for the Toronto Metropolitan Area, approximately 5\% of car commuters are recent immigrants and approximately $6.5 \%$ of public transport commuters are recent immigrants (Boisjoly et. al., 2019). In a study of 32 Filipino participants done in Toronto, $41 \%$ of Filipinos commuted by car (Thomas, 2013a).

Additionally, if Canada was to completely stop new immigrants from moving into Canada, Canada's economic growth and labour force would shrink significantly. The Conference Board of Canada has estimated economic growth would slow from a trend rate of $1.9 \%$ to an average of $1.3 \%$ (The Conference Board of Canada, 2019). By 2034, it is expected that immigration will account for $100 \%$ of the population growth as the number of deaths in Canada may exceed the number of births. With a potential increase of annual immigration to $1 \%$ of Canada's population by the early 2030s, this would support modest labour force and economic growth (El-Assal \& Fields, 2018).

This research surrounds the question on "What are the differences in travel behaviour outcomes in Asian \& European immigrants as they reside in the GTHA for longer timeframes and how does this compare to travel behaviour outcomes of non-immigrants?" More specifically analyzing the differences in vehicle ownership and vehicle-kilometers traveled (VKT). The analysis and quantitative research was primarily completed using an online survey that was administered in 2018 for a study to establish a baseline of data on consumer travel behaviour and knowledge and interest in Automated Vehicles (AVs) (Rajevan, Shi, \& Sweet, 2019). This AV study helped to understand travel behaviours of different populations and learn what motivated 
the survey participants to their travel decisions. In this paper, various methods were used to analyze the data in order to determine the relationships and differences in travel behaviour (in terms of auto ownership and vehicle-kilometers travelled (VKT)) between recent immigrants, immigrants who have resided in the GTHA for longer timeframes, and non-immigrants. The results use VKT and vehicle ownership models to explore the differences in travel behaviour outcomes in Asian \& European immigrants as they reside in the GTHA for longer timeframes in comparison to travel behaviour outcomes of non-immigrants. 


\section{LITERATURE REVIEW}

The literature used in relation to this topic is primarily from an international context, specifically the U.S. Some of the findings from the following literature suggest that there is minimal information on examining commute distance and commute mode (in the GTHA) among immigrants, immigrants travel far less than native-born residents in personal vehicles Blumenberg, 2008; Blumenberg, 2011; Chatman, 2013; Guiliano, 2003), and immigrants have shorter commute distances than non-immigrants (Burke et. al, 2015). Additionally, when advising for changes to local services, it is important for transportation planners to understand the differences in behaviours between demographic groups and income levels (Kaur, 2013).

\section{Social \& Income Factors}

Public transit plays a pivotal role in providing access to job locations for populations with limited mobility options (Currie, 2010; Horner \& Mefford, 2005; Manaugh, 2013; Sanchez, Shen, \& Peng, 2004)). There is a positive relationship between access to transportation and economic outcomes among low-income adults (Blumenberg, 2007). In an analysis on immigrant households in Montreal, it was found that $44 \%$ of the population in socially disadvantaged neighbourhoods (as in seen in figure 1) are taking transit (Manaugh, 2013). These neighbourhoods have $32 \%$ of the population indicating they are a visible minority with a median household income of $\$ 33,000$ and that have not completed post-secondary education. Whereas, when observing the overall neighbourhoods in Montreal, $17 \%$ have indicated they are a visible minority and have a median household income of $\$ 52,392$ with only $23 \%$ of the population taking transit. These disadvantaged areas have poor accessibility to employment positions and are transit dependent. Thus, public transit is highly correlated with socio-economic 
circumstances such as minority group and low-income status (Frisken \& Keall, 1978; Manaugh, 2013).

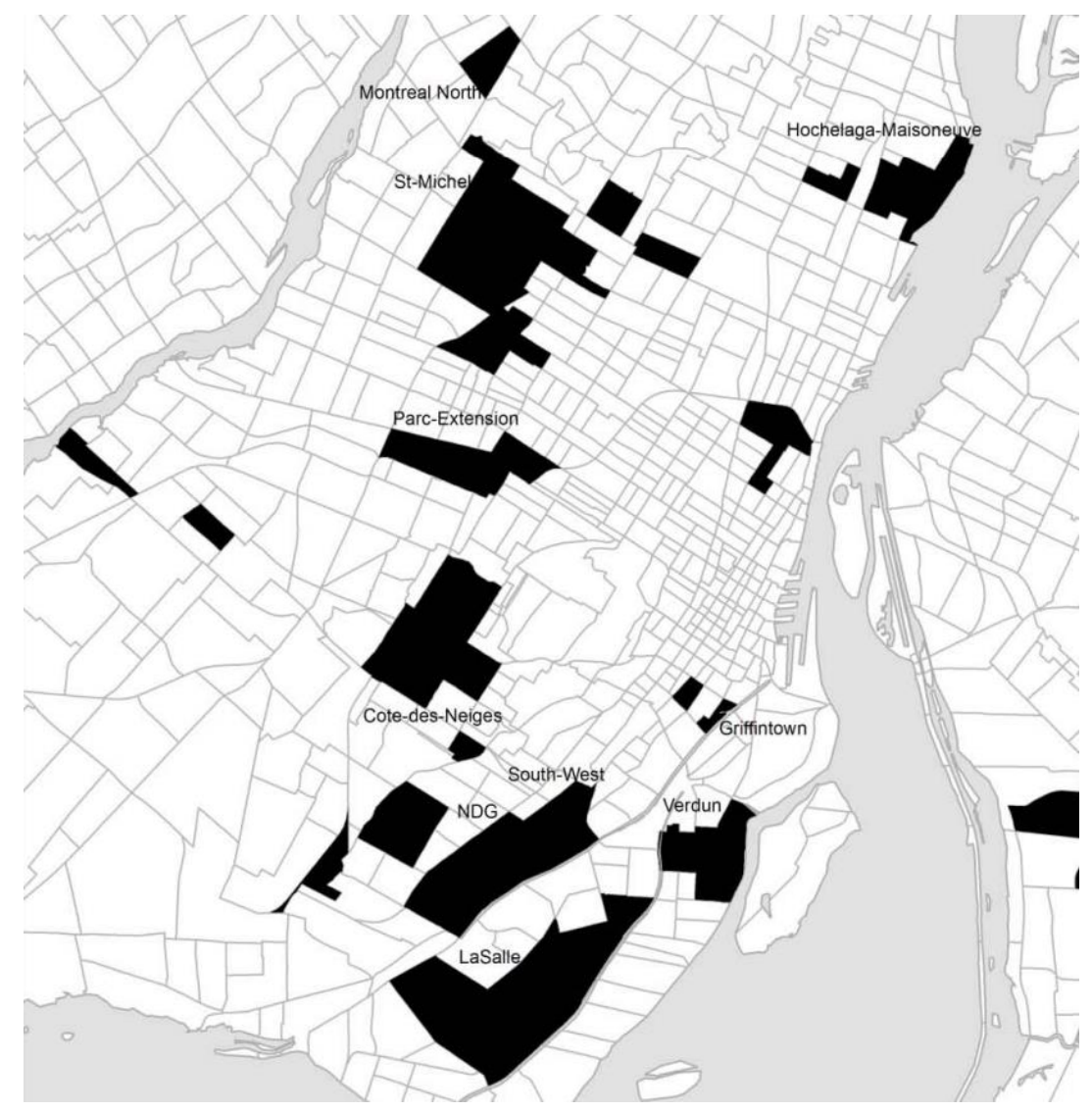

Figure 1: Socially Disadvantaged Neighbourhoods in Montreal (Manaugh, 2013)

Beach's (2003) study indicated that the concentration of people in the same geographic area, who have similar ethnic background, culture, and language serve as vital sources to personal support, financial support, guidance, and information. Transnationalism theory suggests that recent cohorts of immigrants continue to identify strongly with their home countries (Chiang, 2008; Ghosh, 2009; Thomas, 2013b). Many immigrants retain political, social, and employment ties with their home country which can be a challenge as they may avoid integration and settlement in Canada (Thomas, 2013b). 
In the European Union (EU) and Organisation for Economic Co-operation and Development (OECD) countries, "immigrants have higher unemployment rates than the nativeborn” (OECD \& European Union, 2018, p.13). One in four low-skilled jobs are held by an immigrant. Additionally, OECD and EU do not value foreign degrees as much as native ones (OECD \& European Union, 2018). In OECD countries (including Canada), 37\% of immigrants are highly educated, 5\% more than native-born. According to 2017 statistics, immigrants that have landed 5 or less years in Canada had the highest unemployment rate of 9.6\%, immigrants that landed more than 5 to 10 years in Canada had an unemployment rate of $6.2 \%$, and immigrants that landed more than 10 years in Canada has an unemployment rate of 5.6\%. The overall unemployment rate for all Canadian immigrants was 5\%. Of all visible minority groups, African-born immigrants had the highest unemployment rate of all immigrant groups and was particularly high for those who had been in Canada for 5 years or less (Fields \& Yssaad, 2018). These statistics may have a large effect on how immigrants travel differently from native-born residents. Many lower educated households are forced to search for jobs at far distances from their residence (Jeekel, 2019).

Using data from the U.K. National Travel Survey, Bates' (2017) study noted that key differences in travel behaviour were seen belonging to a vulnerable population group (ie. nonwhite or disabled), differences in household income, having a driver's license, and from households with children.

\section{Travel Commute Mode}

Single occupancy vehicles were found to be the primary commute mode for immigrants in the United States (U.S.) (Blumenberg, 2007; Blumenberg, 2008). However, immigrants travel far less in personal vehicles than U.S. born residents (Blumenberg, 2008; Blumenberg, 2011; 
Chatman, 2013; Guiliano, 2003). The longer they live in the U.S., their reliance on vehicles was found to increase (Blumenberg, 2013; Chatman, 2013). Ethnic enclaves may reduce auto use as these enclaves are in dense, mixed-use, and transit-accessible neighbourhoods. Chatman (2013) suggests it may be beneficial to orient transit-oriented development and smart growth policies in the U.S. towards immigrants, as they may be an important part of the policies' potential success and failure. Southeast Asians in California have reported that the most challenges they face with travel is due to auto-related issues such as the unreliability and age of vehicles (Blumenberg, 2007).

There is a need for both group-specific and universal transportation policies and programs addressing transportation needs for low-income families which may link immigrants to the workforce. In almost every city, automobiles remain the fastest and reliable type of transportation (Blumenberg \& Waller, 2003). When observing work-trip mode choice, vehicle availability is often considered as one of the most significant factors (Titheridge and Hall, 2006). Automobiles offer instant availability, flexibility, convenience, and high speed which is not comparable to other alternative modes (Anable and Gatersleben, 2005; Kim and Ulfarsson, 2008). Anable and Gatersleben (2005) argued that freedom and sense of control are influential factors for travel choice which is why non-automobile modes should increase their competitiveness in order to satisfy people.

Literature suggests that U.S. immigrants, especially newly arrived immigrants, are more transit dependent in comparison with U.S. born commuters (Bartholomew et. al. 2014; Beckman \& Goulias, 2008; Blumenberg, 2008; Blumenberg \& Smart, 2014; Chatman \& Klein, 2013; Handy et al., 2008; Smart, 2015; Tal \& Handy, 2010; Taylor et. al., 2009; Transportation Research Board, 1996). In Canadian cities, immigrants also have higher rates of commuting by 
transit (Heisz \& Schellenberg, 2004; Alshalalfah, Lo, \& Shalaby, 2011; Thomas, 2013a). This emphasizes the opportunity to develop a better non-automobile transportation system and structure (Kim, 2009). Suggestions included improving fixed-route transit services, expanding paratransit and other door-to-door transit services (Blumenberg \& Waller, 2003). However, Myers (1997) found new immigrant transit use to decline dramatically after residing in the U.S. for at least 10 years, indicating that immigrants adopt to neighbourhood travel behaviours (personal vehicles) as their economic conditions improve.

Results from the American Public Transit Association in 1999 indicate that the White demographic group were the largest transit users at $45 \%$ followed by Africans Americans (31\%), Latin Americans (18\%), and Asians or Native Americans (6\%) (U.S. Department of Transportation, 2000)". Contrarily, Giuliano's study showed that the White demographic group had the lowest transit and walk shares being less than half of any other demographic group (Giuliano, 2003). The Black demographic group used transit and walked the most with more than twice the transit share of any other demographic group. This change may be due to the four-year gap between the studies.

Generally, fare cost and service frequency are significant factors associated with transit use (Taylor et. al., 2009). In Utah, U.S., flat fare transit systems negatively impacted low-income and minority travelers as they frequently used transit and had the tendency to complete shorter trips in comparison with the general population, subsidizing long distance riders (Bartholomew et. al., 2014). However, distance-based fares may benefit low-income and minority groups within compact urban areas close to the city centre.

In a study conducted in Toronto, immigrants were found to be highly dependent on public transit as they mostly reside in the peripheries of Toronto (Kaur, 2013). This study 
highlighted issues such as poor servicing and connectivity of bus networks, limited affordability of public transit, and barriers to accessing work opportunities within the region. Some policy recommendations in this study included harmonizing fares across the Greater Toronto Area at an affordable rate, greater investment in bus networks, and integrating land-use policies through inclusionary zoning, and promoting affordable and rental housing stock along rapid transit corridors. Heisz' (2004) study used 2001 Statistics Canada data and discovered that recent immigrants used public transit to commute to work more than Canadian born-residents even with controlling demographic characteristics, commute distance, income, and residential distance. In the Toronto CMA, the percentage of commuters who used public transportation to work in 2001 are shown in Table 1 (Heisz, 2004):

Table 1 - Comparing public transit commuters

\begin{tabular}{|l|c|c|c|c|}
\hline & Canadian-born & Immigrated & Immigrated 11- & Immigrated > 20 \\
& & within 10 years & 20 years earlier & years age \\
\hline Toronto & $20.7 \%$ & $36.3 \%$ & $26.8 \%$ & $19.9 \%$ \\
\hline
\end{tabular}

As the number of years of immigration increased, the percentage of public transit commuters decreased. In analyzing transportation trends of Filipino immigrants in Toronto, a significant number of Filipinos used public transit to commute to work corresponding to a lower driving rate where $47 \%$ of participants preferred using public transit (Thomas, 2013a). When analyzing access to transit lines between the inner city and suburbs, it was found the straight-line distance in 2006 between immigrant homes and the closest transit line was " $156 \mathrm{~m}$ in the inner city, 244 $\mathrm{m}$ in the inner suburbs, $259 \mathrm{~m}$ in Mississauga, and $327 \mathrm{~m}$ in York Region (Alshalalfah, Lo, \& Shalaby, 2011, p.)". 
Studies have suggested that in comparison to U.S.-born residents, immigrants in the U.S. bicycle, walk, and carpool more often (Blumenburg, 2013; Smart, 2015). It was also found that living in an immigrant neighbourhood has a strong influence on what mode choice immigrant residents use. Carpooling rates and public transit were found to increase with immigrant concentration of the neighbourhood (Blumenburg, 2013; Liu \& Painter, 2012). In addition, factors that influenced immigrant commuting behaviour included: residential location, transit accessibility, education, socialization, household composition, and employment in an ethnic niche (Blumenburg, 2013; Conrad, Welsch, \& Wittowsky, 2018; Liu \& Painter, 2012).

Giuliano (2003) suggested that research on travel behaviour in the U.S. was largely dominated by white populations as they responded the most to these studies compared to other race/ethnicity travel behaviour. Furthermore, the White demographic group was found to travel the most in comparison to the Hispanics and Asians, and the Black demographic group travelled the least. Using the U.S. National level household travel survey (NHTS), recent Asian immigrants were found to walk and bike more often than other demographic groups (Hu, 2017). $\mathrm{Hu}$ (2017) and Kim (2009), suggested that programs and policies such as the use of immigrants' native language on signage and offering information sessions will increase awareness and safety for pedestrians, bicyclists, transit users, and drivers. Additionally, providing culturally-sensitive and easy-to-use transit services within emerging immigrant neighbourhoods allows for mobility options to those who just arrived with limited to no access to cars or driver's licenses. Kim (2009) found immigration history to be strongly associated with work-trip modes in the US and immigrants were found more likely to use non-drive alone trip modes after controlling various household and personal characteristics. 
A case study looking at London U.K. explores how the use of cycling may resonate differently with varying ethnic, gendered, urban, and class identities (Datta et al., 2011). As cycling is a form of 'active transport', it is encouraged to be used frequently for the reason of improving population health. However in many high-income countries, cycling is not frequently used for transport. Bicycling and walking are far more common in European countries in comparison with the United States, Canada, and Australia (Basset et al., 2008). In London, where more than one in three residents are part of a minority ethnic group, $95 \%$ of female cyclists and $85 \%$ of male cyclists identify themselves as White. Cycling is typically preferred by individuals that want to minimize their dependency on others and maximize future-health gain (Datta et al. 2011; Toronto Public Health, 2012). Immigrants and Opportunity

A current major issue in Canada is the large wage gap between immigrants and Canadian born residents. New Canadians earn 10\% less than an average worker born in Canada across all ages, region, gender, and occupation (The Canadian Press, 2019). Additionally, 62\% of university-educated immigrants between the ages of 25 to 54 do not work in a job that fits their educational qualifications. The wage gap is currently costing Canada $\$ 50$ billion a year in GDP according to RBC Economics. This issue may have risen from the failure to recognize work experience and credentials from abroad. Despite higher education levels, Canadian immigrants have lower incomes and higher unemployment rates compared to the Canadian born population (CNW Group, 2011). Immigrant workers have increasingly been paid less than Canadian born workers since the 1970s. In 2006, it was noted that if there were increases to salaries of immigrants to match Canadian born with similar skills, that would cost up to $\$ 30.7$ billion; $2.1 \%$ of the GDP in 2006 (Nadeau \& Secklin, 2010). 
Skilled Canadian immigrants also struggle in the labour market as they face higher levels of unemployment compared to non-immigrants. Oreopoulos' (2011) study in Toronto manipulated thousands of resumes for online job postings to determine the effects of foreign work experience and foreign names on callback rates from employers. Resumes that had English names received more call-backs than those with Indian, Pakistani, Chinese, or Greek names. Also, Canadian work experience increased responses for applicants. The study found that there was substantial discrimination across a variety of occupations towards job applicants with non-English names and foreign experience. A major concern for recruiters was surrounding language skills. The wage gap and higher unemployment rates assist in understanding why immigrants are travelling differently compared to non-immigrants across the GTHA. Additionally, this helps identify what factors are influencing their travel decisions (ie. location, travel costs, and income) and how transportation and community planners can help accommodate for their needs.

It is vital to boost labour market outcomes for family class immigrants as Canada becomes more dependent on immigrants to support economic growth (El-Assal \& Fields, 2018). The economic class (working class) is admitted to Canada based on human capital characteristics such as education, occupation, work experience, language skills, and age. The economic class accounts for most immigrants' contribution to economic growth. Immigrants from the family and refugee classes are admitted based on humanitarian and social needs, which is why they are not expected to contribute to labour market success as much as the economic class. However, family and refugee classes contribute to the economy as well because they tend to have high retention rates in the province they migrated to compared with the economic class. There is a higher likelihood for the family class to live and work in the same province stimulating demand within the economy and increasing labour supply. The higher the labour supply, the more they travel. 
However, there has not been any recent research regarding how far immigrants travel and how travel differentiates among recent immigrants, immigrants residing in Ontario for longer periods of time, and non-immigrants. It is also important to know how dependent immigrants are on personal vehicles in comparison to other modes of transportation such as public transit.

\section{Takeaways}

The above literature suggests that the most prominent commute mode choice among immigrants are single occupancy vehicles. However, compared to non-immigrants, immigrants travel far less by car, and take transit and other commute modes more often than nonimmigrants. Living in an immigrant neighbourhood strongly influences the mode choice immigrant residents use. A large wage gap and high unemployment rates among immigrants may explain why immigrants travel differently in comparison to non-immigrants. Major factors that affect the employment of Canadian immigrants include skills recognition, foreign work experience and education recognition, discrimination, and language skills emphasizing the importance of industry specific language programming. Though there is literature on immigrant travel behaviour in the U.S., Ontario lacks recent literature and studies. More specifically, this study will analyze the differences in travel behaviour -outcomes between recent immigrants, immigrants who have resided in Ontario for longer periods of time, and non-immigrants. 


\section{RESEARCH DESIGN}

This research surrounds the question on "What are the differences in travel behaviour outcomes in Asian \& European immigrants as they reside in the GTHA for longer timeframes and how does this compare to travel behaviour outcomes of non-immigrants?" More specifically analyzing the differences in VKT and vehicle ownership. The analysis and quantitative research was primarily completed using an online survey that was administered between December $8^{\text {th }}$ to $19^{\text {th }}$ of 2018 to establish a baseline of data on consumer travel behaviour and knowledge and interest in Automated Vehicles (AVs) (Rajevan, Shi, \& Sweet, 2019). In this survey, participants were recruited by SSI/Research Now as part of the Transform Lab's AV project team for the City of Toronto. This study helped to understand travel behaviours of different populations and learn what motivated the survey participants to their travel decisions.

The survey collected responses from 3,200 adults in the GTHA between the age of 18 to 75 (Rajevan, Shi, \& Sweet, 2019). Specific data extracted from the survey include the length of residence and immigrant status in Canada, and self-identified ethnicity and population group membership. Individual travel survey data was used for 2,360 respondents who self-identify as being of Asian (473 immigrants and 266 non-immigrants) or European ethnicity (346 immigrants and 1275 non-immigrants). These self-identified ethnicities were chosen to reduce the potential confounding effects of other diverse ethnicities in effecting travel behaviour. Data includes individual and household characteristics, socioeconomic characteristics, and metrics of recent individual travel behaviour. Data on location of residence is used to construct several metrics of built form. The sample was reasonably represented as locational target regions to gather a considerable sample size for each of the cities in the GTHA into the following groups: 1200 respondents for Toronto, 500 respondents for York Region, 499 respondents for Peel Region, 
400 respondents for Durham Region, 301 respondents for Halton Region, and 300 respondents for Hamilton. Additionally, after collection of data, results were weighted to align with observed proportions of the respective age groups, region of residence, and sex based on 2016 Statistics Canada estimates to avoid undersampling and oversampling certain groups (Rajevan, Shi, \& Sweet, 2019). This was considered the most appropriate method to determine current immigrant and demographic group travel behaviour using standards set by Statistics Canada.

\section{Study Area \& Canadian Studies}

Ontario’s Greater Golden Horseshoe (GGH) has rapidly grown over past decades driven by net domestic immigration and in-migration (Burke et al, 2015; Newbold and Scott, 2016). Burke's paper analyzes commute distance by immigrant status and how commute distance differs between ethnic groups. The results indicate that immigrants have a shorter mean commute of $12.1 \mathrm{~km}$ in relation to native-born counterparts of $13.4 \mathrm{~km}$. Figure 2 shows the breakdown of mean commute distance by ethnic group and immigrant status. 


\begin{tabular}{|c|c|c|c|}
\hline & Immigrant & Native-born & $p$ Value \\
\hline \multicolumn{4}{|c|}{ Ethnic and racial population group } \\
\hline Black & 12.4 & 13.6 & 0.0001 \\
\hline White & 12.2 & 13.6 & 0.0001 \\
\hline Chinese & 12.0 & 12.3 & 0.0086 \\
\hline Filipino & 11.5 & 13.6 & 0.0001 \\
\hline Japanese & 10.2 & $13 \cdot 3$ & 0.0001 \\
\hline Korean & 10.5 & 12.3 & 0.0001 \\
\hline Latino & 11.3 & 11.7 & 0.0845 \\
\hline South Asian & 12.2 & 13.1 & 0.0001 \\
\hline Southeast Asian & 11.4 & 12.4 & 0.0001 \\
\hline West Asian & 11.2 & 12.1 & 0.0577 \\
\hline \multicolumn{4}{|l|}{ Year of arrival } \\
\hline $2002-2006$ & 11.4 & & \\
\hline $1997-2001$ & 11.6 & & \\
\hline $1991-1996$ & 11.8 & & \\
\hline $1986-1990$ & 12.7 & & \\
\hline Pre-1986 & 13.1 & & \\
\hline Overall & 12.1 & 13.4 & 0.0001 \\
\hline
\end{tabular}

Figure 2 - Mean Commute Distance in kilometres (Burke et al., 2015).

Newbold and Scott's (2016) paper identified that Ontario's 2006 Growth Plan and the 2005 Greenbelt Plan established a legislative framework to guide population growth and development within southern Ontario. However, migrants moving beyond the Greenbelt were consequently found to have longer commute distances. Overall, travel distance increased the longer an immigrant resided in Ontario but native-born Canadians remained to have the longest travel distance. 


\section{Method}

Various methods are used to analyze the data in order to determine the relationships and differences in travel behaviour (in terms of auto ownership and vehicle-kilometers travelled (VKT)) between recent immigrants, immigrants who have resided in the GTHA for longer timeframes, and non-immigrants. This study begins by using the 2018 travel survey data to present descriptive statistics related to differences between immigrant groups (ie. less than two years, two to ten years, ten to 15 years, and greater than 15 years). This was based on length of residence in Canada, auto ownership and VKT. First, bivariate variable and t-test statistics were used to see if there were any differences between the groups in relation to VKT (ie. how far did one travel yesterday in a personal vehicle). Beyond the tests, the reasons for differences are explained in Table 2 indicating whether they were significant.

Table 2 - Difference of Means Two Sample T-test

\begin{tabular}{|c|c|c|c|c|c|}
\hline P-Values & $\begin{array}{l}<5 \text { (Sample } \\
\text { Size = 135) }\end{array}$ & $\begin{array}{l}\mathbf{5 - 1 0} \\
\text { (Sample } \\
\text { Size = 117) }\end{array}$ & $\begin{array}{l}\mathbf{1 1 - 1 5} \\
\text { (Sample } \\
\text { Size = 103) }\end{array}$ & $\begin{array}{l}\mathbf{> 1 5} \\
\text { (Sample } \\
\text { Size = 654) }\end{array}$ & $\begin{array}{l}\text { Non- } \\
\text { immigrant } \\
\text { s }\end{array}$ \\
\hline \multicolumn{6}{|l|}{$<5$} \\
\hline $5-10$ & 0.11 & & & & \\
\hline $11-15$ & 0.30 & 0.95 & & & \\
\hline$>15$ & 0.07 & 0.72 & 0.88 & & \\
\hline Non-immigrants & 0.01 & 0.49 & 0.61 & 0.06 & \\
\hline
\end{tabular}

Here, we have used an underlying population of residents from Ontario across different years of immigration and non-immigration. This was drawn from the same population of the survey. This t-test determined the probability of any differences between two groups drawn from the same population. The results from this test show p-values comparing the effects of the years of immigration on each other. Smaller p-values that are less than 0.05 indicate there are statistically significant differences between the groups. Table 2 shows that there are large 
differences between non-immigrants and immigrants in terms of travel behaviour (p-values < 0.05). However, it also shows that between different years of immigration, there are not large differences ( $\mathrm{p}$-values $>0.05)$.

Next, inferential models are estimated to formally test the links between immigrant status and travel behaviour outcomes. In these models, other predictors of vehicle ownership and VKT are controlled for and this is designed to separate the estimated effect of 'being an immigrant' from other age, household, income, employment etc. impacts. Logistic regression models of household vehicle ownership were estimated before Tobit regression models of daily VKT were estimated. Tobit regression models were preferred over more conventional ordinary least squares (OLS) regression models based on the truncated nature of the daily VKT variable (asked of the previous day). The model of vehicle ownership is expected to be more robust, as individuals are notoriously estimating their own VKT which may not be accurate. Models developed account for individual characteristics (age, sex, education level, employment status) and household characteristics (household size, composition, and income). 


\section{RESULTS}

The following results uses VKT and vehicle ownership models to explore the differences in travel behaviour outcomes in Asian \& European immigrants as they reside in the GTHA for longer timeframes in comparison to travel behaviour outcomes of non-immigrants. First as shown in the descriptive findings, pivot tables were created to analyze the various relationships between key variables, and to determine the narratives behind the findings. Additionally, the tables assist in identifying how immigrants travel across the GTHA and potentially indicating why they are travelling a certain way. Then the model results are displayed to further analyze the relationships using a linear regression model and a Tobit model. Finally, these results are used is to make conclusions.

\section{Descriptive Findings}

When observing the distance one travels in a day (according to the 2018 survey), new immigrants travel the least and travel farther for every proceeding year. When they stay for more than 10 years in the GTHA, they start travelling less in a day (as seen in Figure 3). This may be justified as recent immigrants tend to fall in a younger age cohort and as years progress, they travel further to look for a better career, affordable properties, and higher income to expand families. Based on this explanatory analysis, immigrant status correlates with age as one arrives to Canada in their peak economic years. After the 10-year threshold, it is possible that they can afford to live closer to their needs, and eventually for seniors, they start retiring where their daily travel reduces drastically. These results also directly align with findings from literature in Ontario, which show immigrants having a shorter mean commute distance compared to nonimmigrants (Burke et al., 2015; Newbold and Scott, 2016). 


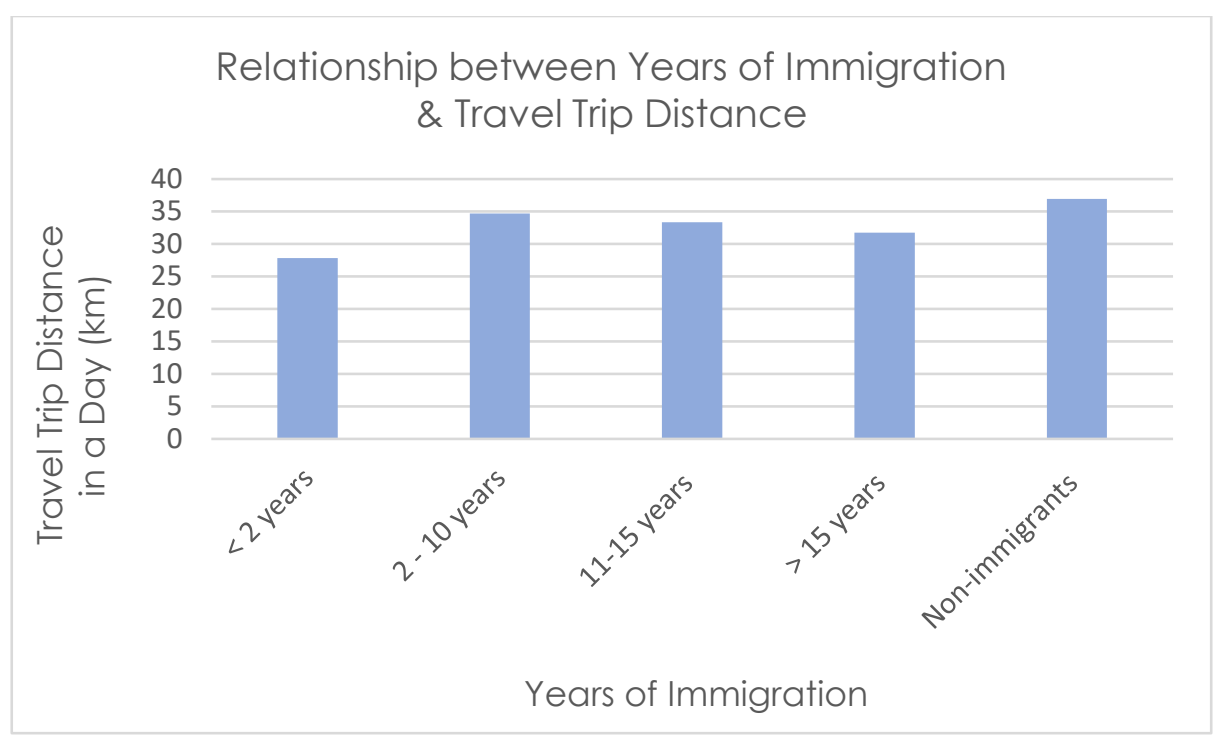

Figure 3 - Comparing the relationship between Years of Immigration \& Travel Trip Distance

Secondly, when observing car ownership in relation to the years of immigration (Figure 4), recent immigrants own the least number of cars. Car ownership then gradually increases the longer they reside in the GTHA with non-immigrants owning the most cars. These relationships possibly indicate that the longer one stays in Canada, the more they adapt to their surrounding environment. In relation to Figure 3, as one travels for longer distances, they may require or depend on having their own vehicle.

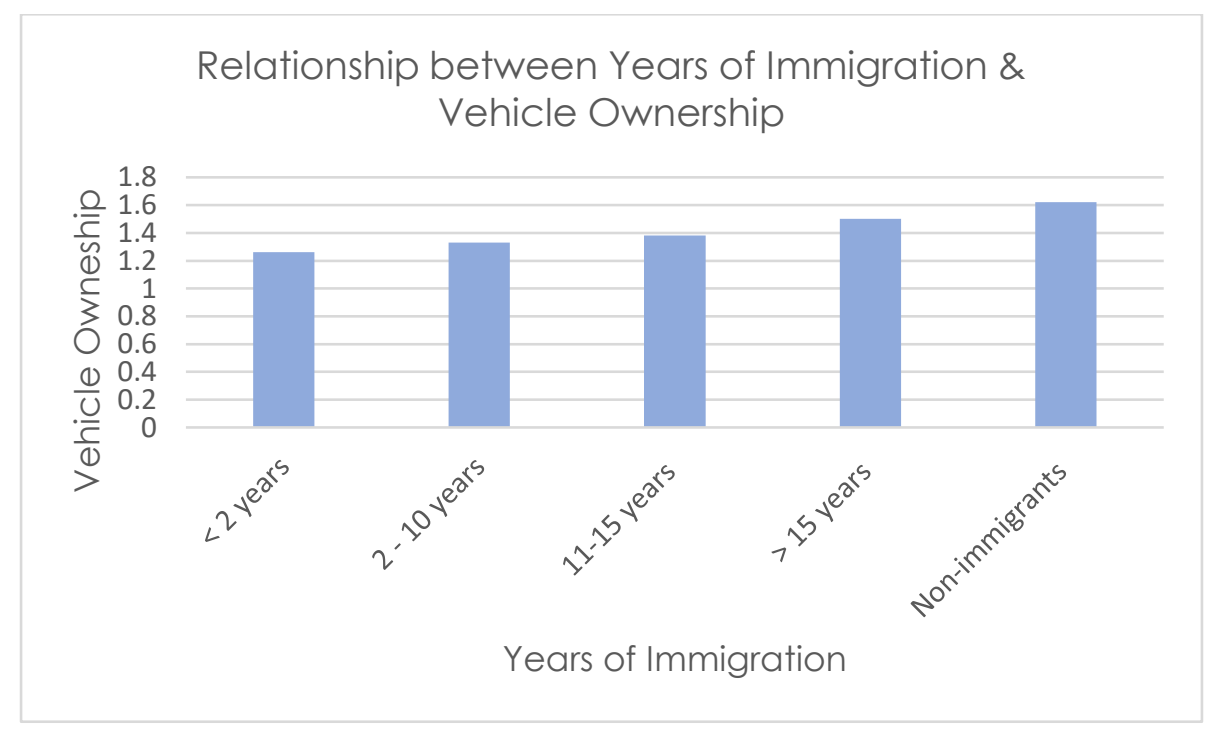

Figure 4-Comparing the relationship between Years of Immigration \& Vehicle Ownership 


\section{Model Results}

In the linear model (Table 3), it shows that employment status, sex, and household size are factors that affect vehicle ownership. However, ethic immigration factors do not seem to have any effect in this model. There is also significant evidence indicating that females are travelling 40\% less VKT than males (Female to Male VKT in Table 3) and that for each additional person in a household, it is expected for the household travel to increase by $25 \%$. In addition, there is some indication that the less than two years immigrant group is travelling less. There is also weak indication that the two to ten-year immigrant group is travelling more. The logit model (refer to Table 3) uses data on whether one has driven yesterday or not and analyzes vehicle ownership. This model shows that there is no large effect on VKT because vehicle count is highly significant thus absorbing most of the variation.

When removing vehicle count, this model shows that if income rises, the probability of owning a car also rises, and employment status and household size become significant factors. Immigrants who have been in Canada for less than two years are less likely to own a car and immigrants within two-ten years of residing in Canada are more likely to own a car. However, when vehicle count was included in the logit model, these factors were not significant. There are some suggestive results showing that part of the reason for factors being significant is due to immigrants in the first few years being less likely to own cars. Thus, the immigrant effect is really about vehicle ownership rather than VKT. The reason why there is a large effect on the model is due to the lower rates of vehicle ownership. Conversely for the second group, controlling for household income and other factors, vehicle ownership levels appear to be higher for this second group (two-ten years of immigration). 
Table 3-Logit Model - Whether Respondent's Household Owns >=1 Vehicle

\begin{tabular}{|l|l|l|}
\hline Dependent Variable & \multicolumn{2}{|l|}{$\begin{array}{l}\text { Whether Respondent's Household } \\
\text { Owns >= 1 Vehicle }\end{array}$} \\
\hline & Estimate & P-Value (Significance) \\
\hline Age & 0.020 & $0.001 * *$ \\
\hline Income - \$15k-\$39k & 0.671 & $0.025 *$ \\
\hline Income - \$40k-\$59k & 1.195 & $0.0001 * * *$ \\
\hline Income - \$60k-\$99k & 1.939 & $2.51 \mathrm{e}-10 * * *$ \\
\hline Income - \$100k-\$124k & 2.588 & $1.30 \mathrm{e}-11 * * *$ \\
\hline Income - \$125k-\$174k & 2.508 & $2.07 \mathrm{e}-10 * * *$ \\
\hline Income - \$175k and above & 2.987 & $2.74 \mathrm{e}-08 * * *$ \\
\hline Female to Male VKT & -0.224 & 0.121 \\
\hline Household Size & 0.283 & $7.23 \mathrm{e}-05 * * *$ \\
\hline $\begin{array}{l}\text { Immigrant Tenure: }<2 \\
\text { years }\end{array}$ & -1.181 & $0.017 *$ \\
\hline $\begin{array}{l}\text { Immigrant Tenure: } 2-10 \\
\text { years }\end{array}$ & 0.988 & 0.203 \\
\hline $\begin{array}{l}\text { Immigrant Tenure: }>10 \\
\text { years }\end{array}$ & 0.257 & 0.381 \\
\hline
\end{tabular}

Note: Level of significance denoted at $0.10(),. 0.05(*), 0.01(* *)$, and $0.001(* * *)$-levels or better.

In the binary logistic regression model, age is highly significant, income effects are getting larger with higher incomes, and household size matters largely (refer to Table 3). Other variables that include education status and retired households were not included in both of the final models (Table $3 \& 4$ ) as they did not have much significance on the model or create any change. However, age, income, comparing female to male VKT, household size, and immigrant tenure all had significance or influenced the models which is why these variables were tested for. The fundamental finding is that in the first two years of being an immigrant, you are less likely to own a car. Then, there is some evidence that suggests after the first two years, there is a higher 
chance of owning a vehicle. When adding specific factors such as being an Asian immigrant and non-Asian immigrant to the model, the results show that there is not a significant difference between Asian and non-Asian immigrants in VKT over different years of immigration. Household income and household size is shown as highly significant, education becomes somewhat significant, and employment status is significant. In the first two years for Asian immigrants, there is evidence that there is an impact on travel behaviour, and same effect for individuals that are not Asian. This suggests that there is not much of a difference in travel between ethnicities, but in general for an immigrant, it is challenging to own and travel by a vehicle for the first two years.

When analyzing scenarios of VKT, there are individuals that do not drive far distances and only drive specific days, whereas some individuals drive continuously for work. There are two different decisions being made which include whether to drive and how far to drive. However, the logit model only assumes how far one drives, not whether to drive. Whereas the Tobit model deals with both decisions simultaneously. This is a censored model implying that it conceives the idea of driving, where the value of $0 \mathrm{VKT}$ is seen as the tendency of not driving on that particular day, instead of assuming that the survey participant has not been driving entirely. The predicted probability is added to the Tobit model to see how far someone travelled yesterday accounting for the fact that they did or did not travel by car. In the Tobit model, the r-square value of 0.3 is much better than the logit model $r$-square value of 0.1 indicating that the Tobit model produces better results. The Tobit model shows different possible scenarios of how far one is travelling by vehicle. The model also captures whether one in fact travels by vehicle. Essentially, this is the predicted probability indicating that one travels by car. The model shows 
that none of the covariates give an independent effect on how far one is travelling. Thus, both processes are very similar.

Table 4 - Tobit Model - Vehicle Kilometers Travelled Yesterday

\begin{tabular}{|c|c|c|}
\hline \multirow[t]{2}{*}{ Dependent Variable } & \multicolumn{2}{|c|}{ Vehicle Kilometers Travelled Yesterday } \\
\hline & Estimate & P-Value (Significance) \\
\hline Age & -0.037 & 0.059 . \\
\hline Income - $\$ 15 \mathrm{k}-\$ 39 \mathrm{k}$ & 0.873 & $0.001 * *$ \\
\hline Income - $\$ 40 \mathrm{k}-\$ 59 \mathrm{k}$ & 1.550 & $5.96 \mathrm{e}-09 * * *$ \\
\hline Income - \$60k-\$99k & 1.764 & $7.07 \mathrm{e}-12 * * *$ \\
\hline Income - $\$ 100 \mathrm{k}-\$ 124 \mathrm{k}$ & 1.889 & $1.78 \mathrm{e}-12 * * *$ \\
\hline Income - \$125k-\$174k & 1.924 & $1.45 \mathrm{e}-12 * * *$ \\
\hline Income - $\$ 175 \mathrm{k}$ and above & 1.956 & $5.95 \mathrm{e}-12 * * *$ \\
\hline Female to Male Vkt & -0.177 & $0.029 *$ \\
\hline Employed part time & -0.280 & $0.048 *$ \\
\hline Work at Home part time & -1.080 & $1.42 \mathrm{e}-05 * * *$ \\
\hline Unemployed & -1.085 & $8.74 \mathrm{e}-11 * * *$ \\
\hline Not in the labour force & -0.957 & $5.50 \mathrm{e}-05 * * *$ \\
\hline Retired & -0.701 & $5.07 \mathrm{e}-05 * * *$ \\
\hline Household Size & 0.110 & $0.0001 * * *$ \\
\hline $\begin{array}{l}\text { Immigrant Tenure: }<2 \\
\text { years }\end{array}$ & -0.224 & 0.566 \\
\hline $\begin{array}{l}\text { Immigrant Tenure: } 2-10 \\
\text { years }\end{array}$ & 0.495 & $0.065 *$ \\
\hline $\begin{array}{l}\text { Immigrant Tenure: }>10 \\
\text { years }\end{array}$ & 0.121 & 0.447 \\
\hline
\end{tabular}

Note: Level of significance denoted at $0.10(),. 0.05(*), 0.01$ (**), and 0.001 (***)-levels or better.

The basic Tobit model shows that there is weak evidence of immigrants in the first two years having lower rates of VKT in comparison to non-immigrants and that there is some degree 
of difference in travel between Asian and non-Asian immigrants. From years two-ten, there is a higher probability of VKT with a significance of 0.034 , but it is weak relative to non-immigrant non-Asians. Essentially, this is the story that is emerging for all the models where there is lower VKT in the first two years but then there is a compensation happening for two-ten years (with significance of 0.09), where there is a push for automobility. Also, this model is accounting for the probability of travelling by car and how far one is travelling by car. The final Tobit model (refer to Table 4) breaks down the Asian status from the non-Asian model and does not include vehicle count. This shows that among Asians, the effect for the first two years is very weak and statistically not significant. Among Asians in year two-ten, there are higher rates of VKT in comparison to non-Asian non-immigrants when accounting for household size, income, and job type. Among the non-Asian group, this shows there is lower rates of VKT among the less than two years of immigration, and every other group is statistically insignificant. When vehicle count is added to this model, all the effects disappear showing that this story is about auto ownership and partially about VKT (due to auto ownership). Other variables such as work at home part time, unemployed, not in the labour force, and retired are also all significant factors that influence VKT and immigrant travel behaviour. All of these variables impacted VKT because when one has not travelled for work or has travelled less on a daily basis, their daily VKT would have decreased. Figure 5 in the Appendix shows the results from both the Tobit and logit models to display what factors were included in the models and their significance. 


\section{CONCLUSION}

The results from this study in the GTHA have similar results to literature findings in the U.S. which indicate that recent and new immigrants own less vehicles and commute less by personal vehicles in comparison to longer residing immigrants and non-immigrants. However, this study helps fill the gap on immigrant travel behaviour in terms of VKT and vehicle ownership within the GTHA. This study also suggests that household income strongly influences travel decisions in terms of VKT and auto ownership. More specifically, lower household income among new immigrants decreases the opportunity for new immigrants to own person vehicles and travel by car.

To determine and meet the needs for immigrant mobility, transportation planners require a better understanding of travel behaviour by diverse immigrant groups. Immigration has become the primary reason for population growth in Canada and the U.S. (The Conference Board of Canada, 2019; Thomas, 2013). Evidence indicates that immigrants use non-auto modes significantly more than non-immigrants but slowly adapt to becoming more auto-oriented as time passes (Chatman, 2013). This study explored daily vehicle travel and auto ownership among self-identified immigrants and non-immigrants with self-identified Asian or European descent in the GTHA.

Data from the 2018 travel survey of residents in the GTHA was used. This includes the length of residence and immigrant status in Canada, self-identified population group and ethnicity, and travel behaviour to explore links between the length of residence in Canada and immigrant status and several mobility measures. This includes auto ownership and vehicle travel distance. The study first used travel survey data to present descriptive statistics in relation to the differences between immigrant groups, based on auto ownership and the length of residence in 
Canada and VKT. Inferential models are then used to estimate and formally test the links between travel behaviour outcomes and immigrant status. The difference of means t-test was used to determine the probability of any differences between two groups that draw from the same population which indicated that there are large differences between immigrant and nonimmigrants in travel behaviour $(\mathrm{p}$-values $<0.05)$ but no large differences between various years of immigration ( $\mathrm{p}$-values $>0.05)$.

Descriptive findings from this study support the expectation of significant differences among self-identified ethnicities (Asian or European) and immigrant status (based on length of stay) and both VKT and vehicle ownership. However, inferential models from this study have shown a complex story. Logistic regression models of household vehicle ownership were estimated before estimating Tobit regression models of daily VKT. Models of household vehicle ownership (yes/no) indicated that, being a recent immigrant to Canada is associated with lower vehicle ownership rates but this rises rapidly the longer one resides in Canada. The spike in vehicle ownership in year 2-10 for immigrants suggests that their travel is changing to a more auto-oriented mindset and may follow the travel patterns of longer residing immigrants and nonimmigrants (who primarily use personal vehicles as the main mode of transportation).

Tobit models of daily VKT suggested lower rates of auto ownership causing VKT reductions. The Tobit model suggested that there is weak evidence that immigrants in the first two years have lower rates of VKT compared to non-immigrants and that there is some degree of difference in travel between Asian and non-Asian immigrants. Also, the model showed that from years $2-10$, there is a higher but weak probability of VKT relative to non-immigrant non-Asians. This is essentially the story that is emerging for all the models where in the first two years of immigration, there is a lower VKT but then the VKT increases for 2-10 years of immigration. 
The final Tobit model displayed that among Asians, the effect for the first two years is very weak and statistically not significant. Among Asians in year 2 to 10, there were higher rates of VKT in comparison to non-Asians non-immigrants.

To conclude, this research will aid transportation planners in understanding travel behaviour of immigrants in Ontario and plan and alter infrastructure to support ethnic group and immigrant travel in Ontario. The change in vehicle ownership and VKT between recent immigrants and immigrants that have resided in Canada for 2 to 10 years shows transportation planners that recent immigrants require infrastructure to access alternate modes of transportation (transit, car pooling) to travel to their desired locations and for work. These work locations may be in rural areas that is inaccessible to public transit. Measures such as improving transit infrastructure, cutting transit fares, and increasing the frequency of transit may promote public transit to immigrants giving more reasons to why they should be taking those modes instead of purchasing and using personal vehicles for their convenience. Further studies and future research is required surrounding the topic of immigrant travel behaviour in the GTHA to determine the daily travel needs of immigrants. 
Table 5 - Final Tobit \& Logit Model Summary Results

\begin{tabular}{|c|c|c|c|}
\hline & & Model 1 (Tobit) & Model 2 (Logit) \\
\hline & Dependent Variable & $\begin{array}{l}\text { Vehicle Kilometers } \\
\text { Traveled Yesterday }\end{array}$ & $\begin{array}{l}\text { Whether Respondent's } \\
\text { Household Owns >=1 Vehicle }\end{array}$ \\
\hline & & P-Value (significance) & P-Value (significance) \\
\hline \multirow{8}{*}{ 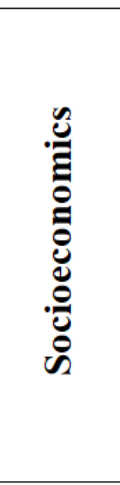 } & Age & 0.059 . & $0.023 * *$ \\
\hline & Income - $\$ 15 \mathrm{k}-\$ 39 \mathrm{k}$ & $0.001 * *$ & $0.001 * *$ \\
\hline & Income - \$40k-\$59k & $5.96 \mathrm{e}-09 * * *$ & $0.025 *$ \\
\hline & Income - $\$ 60 \mathrm{k}-\$ 99 \mathrm{k}$ & $7.07 \mathrm{e}-12 * * *$ & $0.0001 * * *$ \\
\hline & Income - \$100k-\$124k & $1.78 \mathrm{e}-12 * * *$ & $2.51 \mathrm{e}-10 * * *$ \\
\hline & Income - \$125k-\$174k & $1.45 \mathrm{e}-12 * * *$ & $1.30 \mathrm{e}-11 * * *$ \\
\hline & Income - \$175k and above & $5.95 \mathrm{e}-12 * * *$ & $2.07 \mathrm{e}-10 * * *$ \\
\hline & Female to Male Vkt & $0.029 *$ & 0.084 . \\
\hline \multirow{6}{*}{ 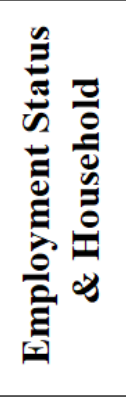 } & Employed part time & $0.048 *$ & 0.402 \\
\hline & Work at home part time & $1.42 \mathrm{e}-05 * * *$ & $0.012 *$ \\
\hline & Unemployed & $8.74 \mathrm{e}-11 * * *$ & $0.0002 * * *$ \\
\hline & Not in the labour force & $5.50 \mathrm{e}-05 * * *$ & 0.118 \\
\hline & Retired & 5.07 e $-05 * * *$ & 0.684 \\
\hline & Household Size & $0.0001 * * *$ & $7.23 \mathrm{e}-05 * * *$ \\
\hline \multirow{2}{*}{ 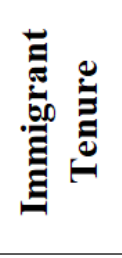 } & Less than 2 years & $0.034 *$ & $0.017 *$ \\
\hline & 2 to 10 years & 0.09 . & 0.176 \\
\hline \multirow{3}{*}{ 兽 } & measure 1 & -- & 0.3 \\
\hline & measure 2 & -- & 12899 \\
\hline & measure 3 (r-square value) & 0.32 & - \\
\hline
\end{tabular}

Note: Level of significance denoted at $0.10(),. 0.05(*), 0.01(* *)$, and $0.001(* * *)$-levels or better. 


\section{REFERENCES}

Alshalalfah, B., Lo, L., \& Shalaby, A. (2011). Relationship between Immigrant Settlement Patterns and Transit Use in the Greater Toronto Area. Journal of Planning and Development, 137(4), pp. 470.

Anable, J. and Gatersleben, B. (2005). All Work and No Play? The Role of Instrumental and Affective Factors in Work and Leisure Journeys by Different Travel Modes. Transportation Research Part A: Policy and Practice 39 (2-3), pp. 163-181.

Bartholomew, K., Farber, S., Habib, K. M. N., Li, X., \& Páez, A. (2014). Assessing social equity in distance-based transit fares using a model of travel behaviour. Transportation Research Part A, 67(Complete), pp. 291-303.

Bassett, D. R., Buehler, R., Crouter, S. E., Pucher, J., and Thomposon, D. L. (2008). Walking, Cycling, and Obesity Rates in Europe, North America, and Australia. Journal of Physical Activity and Health, 5(6), pp. 795-814.

Bates, J., Carrasco, J. A., Lucas, K. \& Moore, J. (2016). Modelling the relationship between travel behaviours and social disadvantage. Transportation Research Part A, 85(2016), pp. 157-173.

Beach C.M., Green, A.G., and Reitz, J. G. (2003). Canadian Immigration policy for the $21^{\text {st }}$ century. Kingston, ON: Queens University School of Policy.

Blumenberg, E. (2007). Immigrants and transport barriers to employment: The case of Southeast Asian welfare recipients in California. Transportation Policy, 15, pp. 3342. 
Blumenberg, E., Donahue, M., Handy, S, Lovejoy, K., Rodier, C., Shaheen, S., Shiki, K., \& Song, L. (2008). Travel Behaviour of Mexican and Other Immigrant Groups in California. Berkeley Planning Journal, 21(1), pp. 1-24.

Blumenberg, E., Lucas, K., \& Weinberger, R. (2011). Auto Motives: Understanding Car Use Behaviours. Bingley, UK: Emerald Group Publishing Limited.

Blumenberg, E. (2009). Moving in and moving around: immigrants, travel behaviour, and implications for transport policy. The International Journal of Transportation Research, 1(2), pp. 169-180.

Blumenburg, E., \& Smart. (2013). Brother can you Spare a Ride? Carpooling in Immigrant Neighbourhoods. SAGE Journals: Urban Studies, 51(9), pp. 1890-1971.

Blumenberg, E. \& Waller, M. (2003). The Long Journey to Work: A Federal Transportation Policy for Working Families. Retrieved from https://search-proquestcom.ezproxy.lib.ryerson.ca/docview/1794157291?pq-origsite=summon

Boisjoly, G., Ciu, B., El-Geneidy, A., \& Levinson, D. (2019). Accessibility and the journey to work through the lend of equity. Journal of Transport Geography, 74, pp.269-277.

Burke C., Newbold, K. B., \& Scott, D. M. (2015). Immigrant status and commute distance: an explanatory study based on the greater Golden Horeshoe. Transportation, 44(1), pp. 181-198.

Cervero, R., \& Ewing, R. (2010). Travel and the Built Environment. Journal of the American Planning Association, 76(3), pp.265-294.

Chatman, D. G. (2013). Explaining the "immigrant effect" on auto use: the influences of neighborhoods and preferences. Research Gate: Transportation, 41(3), pp. 441-461. 
Chiang, L.-H.N. (2008). 'Astronaut families': transnational lives of middle-class Taiwanese married women in Canada. Social and Cultural Geography, 9(5), pp. 505-518.

CNW Group. (2011). Immigrant wage and employment gaps persist: RBC Economics. Retrieved from https://go-gale-com.ezproxy.lib.ryerson.ca/ps/i.do? p=CPI\&u=rpu_main\&id=GALE\% 7CA275225761\&v=2.1\&it=r\&sid=summon

Conrad, K., Welsch, J., \& Wittowsky. (2018). Exploring immigrants travel behavior: empirical findings from Offenbach am Main Germany. Transportation, 45, pp. 733750.

Currie, G. (2010). Quantifying spatial gaps in public transport supply based on social needs. Journal of Transport Geography, 18(1), 31-41.

Datta, J., Edwards P., Green J., \& Steinbach R. (2011). Cycling and the city: A case study of gendered, ethnic and class identities can shape healthy transport choice. Elsevier, 72(7), pp. 1123-1130.

El-Assal, K. \& Fields, D. (2018). Canada 2040: No Immigration Versus More Immigration. Retrieved from https://www-conferenceboard-ca.ezproxy.lib.ryerson.ca/ e-Library/abstract.aspx $?$ did $=9678$

Fields, A. \& Yssaad, L. (2018). The Canadian Immigrant Labour Market: Recent Trends from 2006 to 2017. Retrieved from https://www150.statcan.gc.ca/n1/pub/71-606-x/71-606x2018001-eng.htm

Frisken, F., \& Keall, M. (1978). A Study of Factors Affecting Travel Behaviour and Transportation Attitudes Among Young Adults. Toronto, ON.

Ghosh, S. (2007). Transnational ties and intra-immigrant group settlement experiences: A case study of Indian Bengalis and Bangladeshis in Toronto. GeoJournal, 68, pp. 223-242. 
Giuliano, G. (2003). Travel, location and race/ethnicity. Transportation Research A, 37(4), $351-372$.

Heisz. A. \& Schellenberg, G. (2004). Public Transit Use Among Immigrants. Canadian Journal of Urban Research, 13(1), 170-191.

Horner, M., \& Mefford, J. (2005). Examining the spatial and social variation in employment accessibility: A case study of bus transit in Austin, Texas. In D. Levinson \& K. Krizek (Eds.), Access to Destinations (pp. 193-214). San Diego: Elsivier.

Hu, L. (2017). Changing travel behaviour of Asian immigrants in the U.S. Scholars Portal Journal, 106(Complete), pp. 248-260.

Hulchanski, J. D. (2007). Canada's dual housing policy: Assisting owners, neglecting renters. Univeristiy of Toronto Centre for Urban and Community Studies Research Bulletin, 38.

Jeekel, H. (2019). Inclusive Transport: Fighting Involuntary Transport Disadvantages. Amsterdam, NL: Joe Hayton.

Kaur, A. (2013). The Place for Immigrants in Toronto's Transit And Transportation City. Retrieved from https://digital.library.ryerson.ca/islandora/object/RULA\%3A3029 /datastream/OBJ/download/The_place_for_immigrants_in_Toronto_s_transit_and_t ransportation_city.pdf

Kim, S, and Ulfarsson, G. F. (2008). Curbing Automobile Use for Sustainable Transportation: Analysis of Mode Choice on Short Home-Based Trips. Transportation 35 (6), pp. $723-$ 737.

Kim, S. (2009). Immigrants and Transportation: An Analysis of Immigrant Workers' Work Trips. Cityscape: A Journal of Policy Development and Research, 11(3). 
Liu, C. Y. \& Painter, G. (2012). Travel Behavior among Latino Immigrants: The Role of Ethnic Concentration and Ethnic Employment. Journal of Planning Education and Research, 31(1), pp. 62-80.

Manaugh, K. (2013). Incorporating issues of social justice and equity into transportation planning and policy (Doctoral dissertation). Retrieved from http://tram.mcgill.ca/Teaching/PhD/dissertations/Manaugh.pdf

Myers, D. (1997). Changes Over Time in Transportation Mode for Journey to Work: Effects of Aging and Immigration. Decennial Census Data for Transportation Planning, 2, pp. 8499.

Nadeau, S. \& Secklin, A. (2010). The Immigrant Wage Gap in Canada: Quebec and the Rest of Canada. Canadian Public Policy, 36(3), pp.265-285.

OECD and European Union. (2018). Settling in 2018. Retrieved from https://www.oecdilibrary.org/docserver/9789264307216en.pdf?expires $=1551113649 \& \mathrm{id}=\mathrm{id} \&$ accname $=$ guest $\&$ checksum $=0480 \mathrm{BBAF} 8719 \mathrm{~B} 5$ 69C1588AA104B93A4B

Ontario Ministry of Tourism, Culture and Sport (2019). Travel Activities and Motivations Survey: Ontario's Immigrant Travel Market and Its Impact on Domestic Travel. Retrieved from http://www.mtc.gov.on.ca/en/research/travel_activities/tams_ immigrant_travel_market.shtml

Oreopoulos, P. (2011). Why Do Skilled Immigrants Struggle in the Labor Market? A Field Experiment with Thirteen Thousand Resume. American Economic Journal: Economic Policy, 3(4), pp. 148-171. 
Rajevan, N., Shi, E. H.Y., \& Sweet, M. (2019). Automated Vehicles in the Greater Toronto and Hamilton Are: Overview from a 2018 Consumer Survey: Part A - Summary and Discussion. (Report A). Toronto, ON: City of Toronto.

Reitz, J. (2012). The Distinctiveness of Canadian immigration experience. Patterns of Prejudice, 46(20), pp. 518-538.

Sanchez, T., Shen, Q., \& Peng, Z. (2004). Transit mobility, jobs access and low-income labour participation in US Metropolitan areas. Urban Studies, 41(7), 1313-1331.

${ }^{1}$ Statistics Canada. (2016). Census Profile, 2016. Retrieved from https://www12.statcan.gc.ca/census-recensement/2016/dppd/prof/details/page.cfm?Lang=E $\&$ Geo1=PR \&Code1 $=35 \&$ Geo $2=P R \&$ Code $2=01 \&$ Da ta $=$ Count $\&$ SearchText $=01 \&$ SearchType $=$ Begins $\&$ SearchPR $=01 \& B 1=A 11$

${ }^{2}$ Statistics Canada. (2016). Census Profile, 2016 Census - Toronto [Census mertropolitan area], Ontario and Ontario [Province]. Retrieved from https://www12.statcan.gc.ca/censusrecensement/2016/dp-pd/prof/details/page.cfm?Lang=E\&Geo1=CMACA\&Code 1=535\&Geo2=PR \&Code2=35\&Data=Count $\&$ SearchText=toronto $\&$ SearchType $=$ Begins $\&$ SearchPR $=01 \& \mathrm{~B} 1=\mathrm{Immigration} \% 20$ and $\% 20$ citizenship $\& \mathrm{TABID}=1$

${ }^{3}$ Statistics Canada. (2016). Focus on Geography Series, 2016 Census - Hamilton, (CMA). Retrieved from https://www12.statcan.gc.ca/census-recensement/2016/as-sa/fogsspg/Facts-CMA-Eng.cfm?TOPIC=7\&LANG=Eng \&GK=CMA\&GC=537

Smart, M. J. (2015). A nationwide look at the immigrant neighborhood effect on travel mode choice. Research Gate: Transportation, 42(1), 189-209. 
Taylor, B. D., Douglas, M., Hiroyuki, I., and Camille, F. 2009. Nature and/or Nurture? Analyzing the Determinants of Transit Ridership Across US Urbanized Areas. Transportation Research Part A: Policy and Practice 43 (1), pp. 60-77.

The Canadian Press. (2019). Report finds immigrants wage gap costing Canada $\$ 50$ billion a year in GDP. Retrieved from https://www.thestar.com/business/2019/09/17/report-findsimmigrant-wage-gap-costing-canada-50-billion-a-year-in-gdp.html

The Conference Board of Canada. (2019). Imagining Canada's Economy Without Immigration. Retrieved from https://www.conferenceboard.ca/press/newsrelease/2018/05/15/imagining -canada-s-economy-without-immigration?AspxAutoDetectCookieSupport=1

Thomas, R. (2013a). Resilience and housing choices among Filipino immigrants in Toronto. International Journal of Housing Policy, 13(4), pp. 408-432.

Thomas, R. (2013b). Viewing Immigrants' neighbourhood and housing choices through the lens of community resilience. Surveys and Perspectives Integrating Environment and Society, 5(1).

Titheridge, H. and Hall, P. (2006). Changing Travel to Work Patterns in South East England. Journal of Transport Geography 14 (1), pp. 60-75.

Toronto Public Health. (2012). Road to Health: Improving Walking and Cycling in Toronto. Retrieved from https://www.toronto.ca/wp-content/uploads/2017/10/967b-TPH-roadto-health-report.pdf

Transportation Research Board. (1996). Decennial Census Data for Transportation Planning: Case Studies and Strategies for 2000: Volume 2- Case Studies. Irvine, CA: National Academy Press Washington. 
US Department of Transportation. (2000). Final Report: Travel Patterns of People of Color. Retrieved from https://www.fhwa.dot.gov/ohim/trvpatns.pdf 